\title{
The Right to Complain in Albanian Civil Service and Its Effects
}

\author{
Myrteza Myftari \\ Faculty Of Justice. Dept. Of Civil Law \\ European University of Tirana
}

\section{Doi:10.5901/mjss.2013.v4n11p656}

\begin{abstract}
The so-called Civil Service has come as early as a result of the need to create an administration capable. Its origins associated with the Han dynasty (206 BC-220 BC). In Europe and America, this practice began to be used later. Creating a modern Civil Service is closely related to the decline of feudalism and the creation of national autocratic states (see W. A. Robson, the civil service in Britain and France,1958) (E. A. Cracker 1968), (F. C. Mosher 1968). In Albania after 90 years among the most important reforms in the public administration, was that of adjustment of labor relations in the public administration, reform that was based on the adoption of basic principles such as meritocracy, depoliticized, professionalism, career, etc... In point of view, on 1996 was initially adopted the "Law on Civil Service", which after three years was replaced by Law No. 8549 dated 11.11.1999 "Status Civil Servants". Important part of the rules laid down in this law is the right to complain, which is presented as a fundamental right of civil servants. However, this right is a right of special civil service, and so applies to a part of the public administration and not to all legal persons constituting public administration in our country.
\end{abstract}

Keywords: Civil Service, the right of appeal, the execution of decisions, the law.

\section{Introduction}

Law aims to be achieved its goal for sustainability, professionalism, efficiency in public administration through the acceptance of special rules in the so-called civil service, the performance of duty and the termination of the labor relation, the civil servants (article 1 of S.C.C).

Essential part of these special rules is the right to complain, which is presented as a fundamental right of civil servants. Placing her in public law regime is in the same philosophy adoption of a special law on the civil service, including the aspect that relates to disputes that may arise during labor relations in the civil service. However it should be said that these rules, including the right to appeal, are special for civil service, and so are valid for part of the public administration and not to all legal persons constituting statutory public administration in the country. Naturally, taking for granted that the purpose of the law is realized through rules that it offers, the question may arise whether, the interest to have an efficient public administration, professional, apolitical, sustainable truly achieved if these rules apply only to a part and not for all public administration. This right to complain, initially closely linked to a special body set up to review the complaints of civil servants before they und tem to exercise their right to appeal in court, and in the Civil Service Commission (CSC). The data reported by the Civil Service Commission in the exercise of the right of appeal by civil servants, tell us that during 2011 are reviewed 261 complaints, 188 of which registered in 2011 and 80 carried out in 2010. Meanwhile in 2010 were registered 259 complaints, of which the Civil Service Commission had examined 179 and 80 were transferred to 2011. During 2011 there were only seven complaints reviewed by the Civil Service Commission. Data not showing himself volume of exercise of the right to appeal to civil servants (see annual report o K.SH.C- 2011), but at the same time the topology of the problem is reflected in the civil service and which is reflected in the civil service appeal. The analysis that follows focuses on the legal regime guaranteeing the right to complain to the civil service and the important aspects related to the consequences of its exercise.

Law on the status of civil servant guarantees the right to complain at all stages of the employment relationship of a civil servant (or such candidate).

Law on the status of civil servant is a law with specific application area. The law provides a vertical and horizontal expansion set, thus limiting the enjoyment of civil servant status for a part of public administration. Thus, the horizontal extension of the scope of the law on the status of civil servant is limited to central and independent institutions as defined in law, and as defined in

For a clear analysis, will need to make the distinction of nature that appeals to different aspects related to the civil 
service. Any complaint or appeal request that CSC exercised at first. CSC is an independent institution tasked with the supervision of the management of the civil service at all institutions falling in the scope of this law (article 5 of Law S.C.S). CSC, although I created causes as outside judicial institution, was named sin are clearly present quasi-judicial body. In this form the Supreme Court has described the nature of the CSC.

\section{Civil Service - The Special Arrangement as Part of Public Law}

One public administration reforms of the Republic of Albania after 90 years it was the regulation of the labor relation, in public administration. This reform was based on the adoption of basic principles such as meritocracy, professionalism, career during the practice of labor relations. It thus reflected the approach according to which the issue of regulation of labor relations in the public administration is considered a matter of public law (Cardona F-2002). In this regard, in 1996 the law was first passed the civil service (Law No.8095), who after three years was almost entirely replaced by Law no. 8549 dated 11.11.1999 "status of civil servant '. Last law is still in effect even though a whole steps are taken to replace it with a new law (see www.pad.gov.al) that is being developed as a result of the problem that has emerged as the country's civil service, as well as the need for reform associated with the integration process (see sigma European Principles for Public Administration) . Regarding the latter may be mentioned that N. 110 The SAA states as needed creating a transparent administration, open, accountable and coherent, as well as institutional strengthening, providing impartial recruitment procedures, human resources management, career development, training, promotion of ethics public administration and development of information technologies in the field of Government, that such measures be taken as the central and local institutions (law no.9590).

\section{The Right to Appeal to the Civil Service}

Law on the status of civil servant guarantees the right to complain at all stages of the employment relationship of a civil servant (or such candidate):

Article. 8 provides that "Civil Service Commission has the following powers: a) handling appeals of decisions concerning admission to the civil service, probation, promotion, lateral transfer, evaluation, discipline, rights and civil servant ...".

- Section. 13, paragraph 6 provides that appeals for development and competition results are presented in the civil service commission, within thirty working days of the publication of the findings in two newspapers with the largest circulation. If an appeal is successful, the applicant will be proposed to the institution for the next available the same category and level that he has applied.

- Section. 14, provides that the officer may appeal to the Civil Service Commission, within 30 working days from the communication of the decision.

- Section. 15, paragraph 5 provides that complaints submitted to the development of competition in the civil service commission, within 30 working days of the publication of the results in two newspapers with the largest circulation.

- Article. 20 provides that the civil servant is denied or violated the rights guaranteed by this law, may be able to appeal in writing to the Civil Service Commission.

- Section. 21 provides for appeals against the decision (to release) are presented in the civil service commission, within 30 working days from the communication of the decision.

- Section. 25 provides that while the direct supervisor has the right to take disciplinary action, civil servant of giving its guaranteed through an administrative procedure, which guarantees the right to be informed, to be heard, to be protected and to complain. Also, in the paragraph 5 of this Article provides that appeals against decisions on disciplinary measures presented in the civil service commission, within 30 working days from the communication of the decision.

Subjects are entitled to complain

Law on the status of civil servant is a law with specific application area. The law provides a vertical and horizontal expansion set, thus limiting the enjoyment of civil servant status for a part of public administration. Thus, the horizontal extension of the scope of the law, (see article 2 of law no.8549) on the status of civil servant is limited to central and independent institutions as defined in law, and as defined in Article 2 of this law as follows:

- The central institutions: the Council of Ministers, Ministries.

- Independent institutions: Parliament, Presidency, municipalities, counties and independent central institutions 
(see www.pad.gov.al).

Further, in all these institutions, only certain employees enjoy civil servant status. So the vertical extent of the civil service in our country include: Secretary General, Department Head, department director general and equivalent positions these three categories, department director and equivalent positions: Head and Head office sector and equivalent positions them, and Specialist (see article 13 of law no.8549).

So the civil service and therefore its legal arrangements concerning labor relations, lie only in a part of public administration employees. Even the right to appeal under the rules of the civil service is limited to those that are considered civil servants. It seems as if the law has clearly defined the scope of the civil service in place, but there were some uncertainties in the practical implementation of the exercise of the right to complain. It is quite clearly the case in Parliament, Presidency, Council of Ministers, Ministries, Municipalities and Regions, but to be discussed can be one of the central institutions that rank among the independent part of the civil service bodies. Also, a discussion was even that if the institutions in command of Ministries or Prime Ministers, that qualify as dependent under the law for the Council of Ministers, which are not mentioned among the institutions listed as part of the civil service, may interpreted or not as part of the civil service. In relation to the totality of the central bodies that qualify as independent, we can say that all those who created such site by the Constitution but and by law, be included in the category of part of the civil service institutions. Such are, for example, the Supreme State Ombudsman, the High Council of Justice, the National Council of Radio and Television, The Civil Service Commission, Central Election Commission, Competition Authority, Presidency, etc. In these institutions, only employees who are involved in their vertical civilian employees. Regarding the question whether the subordinate bodies or not part of the civil service, one case that was addressed with a unified decision of the High Court in 2007 (unified decision of High Court no.8) had to do with that if Customs officers enjoy status civil and therefore can they appeal before a civil service commission. Law on the status of civil servant should say that did not mention the bodies that are or may be considered depending on those that are provided by law. Thus, the ministry mentioned in the law as an institution but not mentioned legal persons depending on ministries, such as the General Directorate of Customs, General Directorate of Prisons, Office of Immovable Property Registration, or Regional Education Directorate, etc; which are created with the status of a legal person depending on ministers and / or prime minister. There are times, even among these examples were mentioned, when a special law, not aim on the status of civil servant, I know the status of civil servant employees of the institution, such example is the Directorate General of Taxation that the law on tax procedures provided that is part of the civil service and some of its employees are entitled to civil servant status (law no.9920).

We also refer to this attitude, and the interpretation reference noted above, it can be said that the status of the officer:

- The employees enjoy those expressly provided for in the law on the status of civil servant (horizontal and vertical extent shown above).

- The employees enjoy independent central institutions (whether constitutional or online laid such by the Constitution but by law), for which it should be said that often the relevant laws expressly provided joy of this status.

- The employees also enjoy hanging institutions for which special law expressly provides enjoyment of this status.

- I do not enjoy when employees of institutions or laws regulations governing their operation provided that certain processes or specific events regulated in reference to borrowing arrangements or law on the status of civil servant.

At the end of this analysis, we can say that the right to complain at CSC belongs only to those employees who enjoy the status of civil servant. For a competitive process, the right to complain enjoys even the participants on the process of competition, in reference to the adjustments shown in this analysis (See Table 1).

\section{The Right of Appeal for Acts and Omissions.}

Although in several articles this right is explicitly associated with the creation special moment or exercising employment relationship, it seems that in all these cases the relevant competent authority, are requested adoption of a decision, in any case have to do with the decision - Act nomination to the Department of Public Administration (see article 130), or personnel department depending on the categorization of the body part of the civil service where vacant land was opened, in any case, the decision of the supervisor directly for confirmation or not of the status of civil servant at the end of the probationary period, the any other case of direct supervisor for disciplinary action, or for remuneration, or for 
violations of the rights of civil servants. This attitude is reflected in the principle of decision-making by Article. 15 of the administrative code (A.P.C), which expressly provides for the obligation of the administrative body to adopt a decision whenever there are complaints submitted to him (article 15 of A.P.C). So, the right of appeal is closely related to a decision, which becomes the object of administrative appeals exercising relevant subject, civilian employee or candidate for being such. This aspect is important to note because the process of reviewing administrative and / or judicial is closely linked to an administrative decision and cannot be exercised prior to the relevant administrative act adopted and the second is a review process that addressing decision, addresses the consequences, and return the situation to the previous situation. It is important to note that although not expressly provided a right to complain about omissions, cannot be said that it isn't the right of the parties: example of such a situation would be if the competent authority does not issue the act of appointment to the office of officer winner of the competition. The right to appeal against administrative processes exercised as against the actions and omissions, known causes as a subjective right of the fundamental law of administrative procedures and basic procedural law on which civil trials conducted in the country, and thus IAC (article 140) Code of Civil Procedure (CPC)-(see article 134 \&135). In reference to the sample taken, even though the competition is held, the act of appointment has not come at the end of process as provided for by Art. 13 of the Law on the civil status servant and therefore the parties have the right to request at the relevant bodies, CSC or court, adopting the act of appointment. What can be raised for discussion is within what should exercise the right of appeal in such cases, since there was a special of the estimates of the exercise of the right of appeal for failure in the law on the status of civil servant, will refer to deadlines forecasted by the code of administrative procedures which the article. 140 provide that the right to appeal in cases of omission arises after 3 months of the submission of the initial application. A possible interpretation of these rules by legal, it may be that in such cases The complainant must submit the request to the relevant administrative body for the first removal of the administrative body in charge of appointing and three months of this request not address the right of appeal which is also the deadline for its exercise that is until one month later. While attending further to the period within which to exercise the right of appeal in cases of actions - see table No. 1 for details it should be said that it expected to exercise that right within 30 days from the time of communication of the decision was appealed. An important element in the framework of the principle of due process is that of expectation expressed in the bylaws of the commencement deadline to appeal after the communication so that the recognition decision by appealing subject.

Table No. 1: The right to appeal to the civil service.

\begin{tabular}{|c|c|c|c|c|c|c|}
\hline Article & appeal for & $\begin{array}{l}\text { Subject to } \\
\text { exercise the } \\
\text { right to } \\
\text { complain }\end{array}$ & $\begin{array}{c}\text { The first } \\
\text { recipient of the } \\
\text { right to appeal }\end{array}$ & $\begin{array}{l}\text { The period within which } \\
\text { exercised his right of } \\
\text { appeal }\end{array}$ & $\begin{array}{l}\text { Effects that brings } \\
\text { complaint }\end{array}$ & what set \\
\hline Article & \begin{tabular}{|l|} 
The decision \\
regarding \\
admission to the \\
civil service, \\
probation,
\end{tabular} & civil servants & $\begin{array}{l}\text { The Civil } \\
\text { Service } \\
\text { Commission }\end{array}$ & See below & See below & See below \\
\hline Article & $\begin{array}{l}\text { Development and } \\
\text { outcome of the } \\
\text { competition }\end{array}$ & $\begin{array}{l}\text { Participants in } \\
\text { the } \\
\text { competition }\end{array}$ & $\begin{array}{l}\text { The Civil } \\
\text { Service } \\
\text { Commission }\end{array}$ & $\begin{array}{l}\text { Within } 30 \text { working days } \\
\text { of the publication of the } \\
\text { results in two } \\
\text { newspapers with the } \\
\text { largest circulation }\end{array}$ & $\begin{array}{l}\text { If an appeal is successful, } \\
\text { the applicant will be } \\
\text { proposed to the institution } \\
\text { for the next available the } \\
\text { same category and level } \\
\text { applied }\end{array}$ & $\begin{array}{l}\text { Depending on the } \\
\text { situation: } \\
\text { - changeability of the } \\
\text { competition process. } \\
\text { - Proposal for } \\
\text { appointment of } \\
\text { competitors in the } \\
\text { first place free } \\
\end{array}$ \\
\hline Article & $\begin{array}{l}\text { The decision by } \\
\text { the end of the } \\
\text { probationary } \\
\text { period }\end{array}$ & civil servants & $\begin{array}{l}\text { The Civil } \\
\text { Service } \\
\text { Commission }\end{array}$ & $\begin{array}{l}\text { Within } 30 \text { working days } \\
\text { of the communication of } \\
\text { the decision }\end{array}$ & $\begin{array}{l}\text { No any special } \\
\text { adjustment for the effects } \\
\text { that entails appeal }\end{array}$ & $\begin{array}{l}\text { Depending on the } \\
\text { situation: } \\
\text {-Drop-in power } \\
\text {-Repeal } \\
\text {-Amendment of the } \\
\text { act. } \\
\end{array}$ \\
\hline $\begin{array}{c}\text { Article } \\
15\end{array}$ & $\begin{array}{l}\text { Development of } \\
\text { competition in the } \\
\text { case of parallel }\end{array}$ & civil servants & \begin{tabular}{|l|} 
The Civil \\
Service \\
Commission
\end{tabular} & $\begin{array}{l}\text { The rules are expected to } \\
\text { be the same admission } \\
\text { procedure }\end{array}$ & $\begin{array}{l}\text { No any special } \\
\text { adjustment for the effects } \\
\text { that entails appeal }\end{array}$ & $\begin{array}{l}\text { We forecast that } \\
\text { reflection is the same } \\
\text { procedure with the }\end{array}$ \\
\hline
\end{tabular}




\begin{tabular}{|c|c|c|c|c|c|c|}
\hline & $\begin{array}{l}\text { motion or } \\
\text { promotions }\end{array}$ & & & & & $\begin{array}{l}\text { acceptance } \\
\text { procedure: } \\
\text {-changeability of the } \\
\text { competition process } \\
\text {-Proposal for } \\
\text { appointment of } \\
\text { competitors in the } \\
\text { first place free }\end{array}$ \\
\hline $\begin{array}{c}\text { Article } \\
20\end{array}$ & $\begin{array}{l}\text { Denial or } \\
\text { violation of rights } \\
\text { guaranteed by } \\
\text { this law }\end{array}$ & civil servants & $\begin{array}{l}\text { The Civil } \\
\text { Service } \\
\text { Commission }\end{array}$ & not defined deadline & $\begin{array}{l}\text { No any special } \\
\text { adjustment for the effects } \\
\text { that } \\
\text { entails appeal }\end{array}$ & $\begin{array}{l}\text { Depending on the } \\
\text { situation: } \\
\text {-Drop-in power } \\
\text {-Repeal } \\
\text {-Amendment of the } \\
\text { act. }\end{array}$ \\
\hline $\begin{array}{c}\text { Article } \\
21\end{array}$ & $\begin{array}{l}\text { Decision on } \\
\text { release }\end{array}$ & civil servants & $\begin{array}{l}\text { The Civil } \\
\text { Service } \\
\text { Commission }\end{array}$ & $\begin{array}{l}\text { Within } 30 \text { working days } \\
\text { of the communication of } \\
\text { the decision }\end{array}$ & $\begin{array}{l}\text { No any special } \\
\text { adjustment for the effects } \\
\text { that entails appeal }\end{array}$ & $\begin{array}{l}\text { Depending on the } \\
\text { situation: } \\
\text {-Drop-in power } \\
\text {-Repeal } \\
\text {-Amendment of the } \\
\text { act. }\end{array}$ \\
\hline $\begin{array}{c}\text { Article } \\
25\end{array}$ & $\begin{array}{l}\text { The decision } \\
\text { disciplinary } \\
\text { measure }\end{array}$ & civil servants & $\begin{array}{l}\text { The Civil } \\
\text { Service } \\
\text { Commission }\end{array}$ & $\begin{array}{l}\text { Within } 30 \text { working days } \\
\text { of the communication of } \\
\text { the decision }\end{array}$ & $\begin{array}{l}\text { No any special } \\
\text { adjustment for the effects } \\
\text { that entails appeal }\end{array}$ & $\begin{array}{l}\text { Depending on the } \\
\text { situation: } \\
\text {-Drop-in power } \\
\text {-Repeal } \\
\text {-Amendment of the } \\
\text { act. }\end{array}$ \\
\hline
\end{tabular}

\section{Effects of Exercise of the Right to Appeal at KSHC (CSC)}

Another aspect of the right to complain about is the consequences that come with filing the complaint. As a rule, an administrative appeal brought suspension of the effects of the decision unless the latter has to do with meeting fees, taxes, budget revenue, police action, implementation is in the interests of public order or public health and other interests public, and as provided by law enforcement absence of one or consequence of the act (see article 138 A.P.C). Law on the status of civil servant does not provide any special adjustment related to the effect of the exercise of the right to appeal to civil servants. Bylaws for the implementation of the law on the status of civil servant have forecasts that appear may indirectly relate to this aspect. So for example:

- In DCM. 306, dated 13.06.2000 "for discipline in the civil service" provided that "in the case when the civil servant has taken disciplinary action and dismissal from the civil service and the Commission decides to revoke or amend the decision of the direct supervisor, officer receives full salary from the moment when relations were severed financial establishment ".

- $\quad$ In DCM. 231, dated 11.05.2000 "for admission to the civil service and probation" provided that depending on the decision of the CSC officer recorded in a waiting list for first place in the same position as that for which it has applied or repeated procedures competition from the stage where there were irregularities.

At the same DCM, specifically in its point 30 , provided that if the appeal presented at CSC for the direct supervisor's decision at the end of the probationary period, the institution is required to keep the workplace free until final settlement resolution appeal or until the expiration of the deadline for their submission. I would say that it means to a certain degree the effects of the decision suspending the direct supervisor. I say this because a full suspension would have regardless of whether the officer was a decision without confirmed, will proceed normally working relationships to receiving a decision of CSC that, while simply holding the country provided free, which that in itself is entirely indicative of protection that provides the status of civil servant in the spirit of the law on the status of civil servant.

- We DCM. 360 dated 14.07.2000 "for release from civil service" that civil servants detailed exercises the right of appeal for the release decision for disability and case decision, the Civil Service Commission and the officer receives full salary from the date of termination financial relations, which means you can be and why exercise the right to appeal it brings itself does not suspend the implementation of the act of release, but is CSC's decision that he who will bring this effect. New diagnosis is that in this case the effect is not related to making a final decision, but simply with the decision of the CSC. I think that such a determination under this decision 
of the Council of Ministers respect the legal regulation provided for in N. 8, paragraph 3, which provides that the CSC decisions that are binding on the institutions, without their liability associated with the acquisition of final status.

As seen, the filing of the appeal to different decisions as provided for law enforcement along the decision on the status of civil servant entails no effect of suspending the effect of the act. This approach is not expressly provided for in the law on the status of civil servant, but then I implied by-laws that regulate in detail the exercise of the right to complain. I think that such an issue for the legal nature and not requiring adjustment Welfare. It has to do with the exercise of a right or fundamental subjective human (article 42 of Constitution), that the appeal against the administrative decisionmaking (or inaction), and as such any adjustment of the aspects that have to do with the need to adjust the level of a law. This would bring more clarity and a better protection for anyone who exercises this right. Not in vain IAC N. 138 refers expressly excluded from decision-making or forecasting suspension of such a possibility by special law relating this approach to public interest law anyway.

For a clear analysis, will need to make the distinction of nature that appeal to different aspects related to the civil service. Any complaint or appeal request that CSC exercised at first. CSC is an independent institution tasked with the supervision of the management of the civil service at all institutions falling in the scope of this law (article 5). CSC, although I created causes as outside judicial institution, was named sin are clearly present quasi-judicial body. In this form the Supreme Court has described the nature of the CSC:

- Wearing the features of an administrative body, independent and charged with resolving appeals of decisions concerning civil servants Civil Service Commission has administrative features an arbitrator, or various body with quasi-judicial function and powers.

- Select appeals concerning civil servant in all public administration institutions of central or local, which are regulated by this law, regardless of the scope of activities that develop without being a superior body of any of them (Unifying decision of the Supreme Court No.3).

In this regard CSC is considered a first degree in an administrative trial, and was at the time of filing the complaint with the commission, the party that initiates this process should be clear which party directs its research and based on general principles of civil procedural law "parties to a trial, the object and determined the cause of the claim that the beginning of the trial and can be changed only under conditions that provide for its specific provisions." This attitude of the Supreme Court directs us towards the Great also being considered submitting the appeal at CSC thy how a complaint of an administrative nature clean. So, the legal regime that should appeal to customize the appearance of at CSC should be considered under the same optical, as a remedy that is procedurally appear before a first instance administrative judgment. The general rules of civil procedure that brings deposition on the effects of an administrative claim in court are such that the presentation of a claim does not automatically entail the suspension of the effects of the act, the parties will need to ask specifically due to the advent of this request and the court vevante should decide the intermediate decision on taking this measure. I applied this rule in the case of exercise at CSC appeal that leads us DREH interpretation due to the nature of the institution, the presentation of an appeal does not bring the effect of suspending the effect of the act was appealed. Despite this, in order to reflect the spirit of the law for providing a protective regime for civil servants, in any case provided the country holding of free labor, the expected return instantly to the task of civil servant, if the work is not setting provides free civil servant in the waiting list.

\section{CSC's Decisions on Appeals Filed - Mandatory to be Implemented}

CSC institution as provided by law that resolves claims for labor relations between civil servants and the institution where he works. Being such an institution, which is the legal value of CSC decisions: a CSC decisions are binding that? Are decisions which became final and thus executive titles? The law provides that the CSC decisions that are binding on the institutions of central and local public administration, then I would say to all institutions involved in the field of law enforcement on the status of civil servant (article 5). CSC decisions that are of a special nature, since decisions of a quasi-judicial body, and they themselves will reflect the mixed nature of this decision as the intermediate between that administrative and judicial. This also means that their liability be considered and analyzed in the same perspective. If we had to do with a pure administrative decision, it will be applicable once the law took effect. This means that CSC decisions are obligated to be applied directly (article 130 of A.P.C). AW on the status of civil servant does not provide any time for implementation of the CSC's decision, but own rules of organization and operation of the CSC provides that decisions shall be published within 3 days of their approval and duly notified to the A.P.C (see Regulation of organization and functioning of K.SH.C). 
Also, the nature of the CSC decision that it is not pure administrative acts, but some kind of acts that many of those judicial approach (see law no.8730). Some decisions unifying the Supreme Court have already clearly this position. The High Court concluded that "the decision of CSC that resembles the decision given by the court of first instance, based on its features and coercive power that the legislator has given us when he appealed"(Unifying decision of the Supreme Court No.3). This court has noted that CSC decisions that "1) containing an obligation, 2) have effects executive, 3) we take final form unless appealed, or remain in force by higher courts" (Unifying decision of the Supreme Court No.3). Given that CSC features, it cannot be equated with an administrative body clean and in view of taking over the execution of its decisions: Well CSC is set in law as a body hanging over the parties and that, as and its courts cannot execute its decisions, which in any case as the law provides mandatory. The execution of these decisions is left to the authorities to make the execution of judicial decisions, but after having received the final form (Unifying decision of the Supreme Court No.1). For this, the Supreme Court concluded that "the consequences and the effects these decisions will have to be the same with the consequences and effects that bring the first instance decision, if not appealed or when they take final form." Not only that, but their execution should be made within a reasonable time. Compulsory execution of a final decision of CSC that is handled by the constitutional court (see part 4 of K.P.C).

\section{Brief Presentation of the Problem that Faced the Implementation of K.SH.C (CSC's) Decisions.}

Legal interpretations indicate that the obligation to implement a final decision is undisputed that the K.SH.C (CSC), while the obligation to implement a decision of the K.SH.C (CSC) as soon as he can handle this interpretation. Despite legal interpretations, the data doesn't show all of CSC decisions that have taken final form resulting executed. According to K.SH.C (CSC) " K.SH.C (CSC) activity for 2011" if it turns out that this year 261 decisions were taken by K.SH.C (CSC), 30 have returned to an executive as of the date of approval of the report 20.02.2012 (Resolution No. 17 The K.SH.C). According to K.SH.C (CSC), most decisions that are in favor of civil servants appealed to the appellate court, we report mentioned a few times.

K.SH.C (CSC) considers the report of collision between Article 8 of the law on the status of civil servant and proves that K.SH.C (CSC) decisions that are not considered as an executive (annual report 2011, page 56). I think that this interpretation of the K.SH.C (CSC) should be seen in light of the legal interpretations made now that K.SH.C (CSC) decisions are likened to those of the judiciary, by nature, take final form and in this sense they are required for issuing the order of execution by the K.P.C (CPC) for articles compulsory execution. Attitude that final actions of CSC are required to apply is clearly held by the constitutional court (resolution no.1of constitution court). So there is no room for equivocation in the proper reading of the nature of a final decision of CSC (when they take final form). It was born as concern has to do with the fact that when the CSC decision becomes mandatory to be implemented. Voluntary compliance in any case is related to the moment of gaining legal power, but the right one is related to the transformation of CSC's decision in an executive, which in itself requires compliance with the relevant procedure prescribed by CPC and then the execution by the Executor. A legal amendment in this regard may lead to the implementation of the rapid binding decisions of the CSC.

\section{Comments on the Draft Law on Civil Service, the Need for Legal Changes}

Now, a new bill is designed for civilian service in our country (see www.pad.gov.al). In a span of 18 years since 1996 when the first law was passed on the civil service, this is the third draft; apparently adoption of a new law is seen as the appropriate way to address the problems that occur in connection with labor relations in our public administration and specifically in the civil service. Having not been focused of analyzing the project, it can be said briefly that he intends to address the problems encountered in the implementation of CSC decisions. Draft addresses in a separate complaint under the K.SH.C (CSC), aiming to first appeal to K.SH.C (CSC) treated like any administrative remedy that brings the effect of suspending the effects of the act was appealed, and secondly note that regardless of your right to appeal against decisions the K.SH.C (CSC) that the institution must first implement the decisions of the K.SH.C (CSC), the latter therefore be mandatory to apply to the court before the opposition (article 13 of K.SH.C). Both these attitudes that are proposed in the draft draws on an approach different from keeping up today. They will bring a new approach to efficiency at K.SH.C (CSC's) appeal and the decision of the latter. Such an attitude reinforced deeply and will decide on a new legal regime of K.SH.C (CSC's) decision, bringing an even greater needs protecting for civil servants. Such a prediction would be complete reflection of the goals of a civil service law. However, it should be said that together with this proposal, made another public relating to CSC, it comes out of the draft law on Administrative Courts: bill being discussed in parliament 
which already provides solutions, making decision of appeal related in Civil Service Administrative Court (see www.keshilliministrave.al): Well possible legal solution is that it be referred of the right to complain directly at court.

Such a prediction would be efficiently reflected in the views of specialization, quality, speed and effectiveness of judicial decision making; all these features will be reflected think the administrative court decisions on issues that will be linked to the civil service. However, effectiveness may have been questionable from the viewpoint of the effect that would bring the presentation of such a claim: the presentation of the claim in the Administrative Court under the project does not automatically entail the suspension of the effects of the act for which the claim is presented. However, according to the draft party that raises the lawsuit may require obtaining security measure suit, one of which is the suspension of the effects of the act, and even this measure can also be provided to the filing of the suit, but it means that in any case will have a court decision that under the project will be taken if there is a possibility of the arrival of the heavy damage irreparable arising from the execution of administrative action. Considered the likelihood that such damage that may come from a decision relating to the civil service to be low (in the best case).

\section{Conclusion}

Through civil service legislator intended to help sustainability, professionalism, efficiency, in public administration. The legislator should be clear as written above. The following legal regulations should be adopted in connection with the exercise: The first; the right to appeal against the decision-making governing authorities of the state administration in the civil service. Second; the execution of which shall be the competent authority to review such complaints.

All this in order to be employed in public administration and employees to feel themselves secure in fulfilling their obligations in work place, in compliance with the laws in force, to feel themselves protected from discrimination that may come to them because they impact the rotation policy that provides no legal change of public administration. As well, to be protected from gender discrimination, preferential choice, friendly choice, racial, etc.. These's typical phenomena of the former communist bloc countries such as Albania is, they bring negative consequences in two aspects: First; the legal functioning of public administration in the service of the citizens interests. Second; the discrimination of public administration employees for illegal reasons such as: political, gender, racial, etc..

\section{References}

W. A. Robson, The civil Service in Britain and France, 1956.

E. A. Crackle, The civil Service in Britain and France, 1968.

F. C. Mosher, Democracy and the Public Service, 1968.

Article 1 of S.C.C. Law on the Status of Civil Servants.

See Annual Report of K.SH.C- 2011, Tirana, page 58-74.

Article 5 of Law S.C.S. Law No. 8549 date 11. 11. 1999 "Status of Civil Servants".

Cardona F., Building a Civil Service System, in OECD/Sigma 2002.

Law No. 8095, date 21. 03. 1996 "For civil service in the Republic of Albania"'.

The draft law on civil service in: http://www.pad.gov.al/ligjishc.html.

SIGMA, European Principles for Public Administration, sigma paper no. 27, sigma, Paris, 1999.

Law no. 9590, dated 27.07.2006 "On Ratification of the Stabilization and Association Agreement between the Republic of Albania and the European Communities and their Member States, Annex 2 (b).

See article 2 of Law No. 8549, date 11. 11. 1999 'Status of Civil Servants'.

The draft law on civil service in:: http://www.pad.gov.al/ligjishc.html.

See article 13 of Law No. 8549, date 11. 11. 1999 'Status of Civil Servants'.

Unified decision of High Court no.8, date 12. 09. 2009.

Law No. 9920 19. 05. 2008 "For Tax Procedures in the Republic of Albania".

See article No. 130 I KPA.

Article No. 15 of K.P.C "The principle of taking decision."

Article No. 140 I KPA.

See article No. 134 \& 135 of Law Nr. 8116, date 29. 03.1996 "Procedures Civil Code of the Republic of Albania".

See article No. 138 KPA.

Article No. 42 of Constitution.

Article No. 5 of Law No. 8549, date 11. 11. 1999 "Status of Civil Servants".

Unifying decision of the Supreme Court No.3, date 24. 01. 2007.

Article No. 5 of Law No. 8549, date 11. 11. 1999 "Status of Civil Servants".

See article No. 130 I KPA. 
See Regulation of organization and functioning of K.SH.C. ne: http://www.kshc.gov.al/template.php=48370.

Law No. 8730, dated 18. 01. 2001 "On the organization and functioning of judicial enforcement services".

Unifying decision of the Supreme Court No.3 dated 24. 01. 2007.

Unifying decision of the Supreme Court No.1 dated 17. 01. 2011.

See part 4 of K.P.C.

Resolution No. 17 The K.SH.C. dated 20. 02. 2012, "Annual Report of the Civil Service Commission, 2011", Tirana.

Annual Report 2011, page 56.

Resolution no.1 Constitution Court of Republic of Albania, date 19. 01. 2009.

The draft law on civil service in: http://www.pad.gov.al/ligjishc.html

Article 13 of K.SH.C.

Decision of the Council of Ministers no. 1310, dated 16. 10. In 2008. In http://www.keshilliiministrave.al/?fq=brenda\&m=news\&lid=9502. 